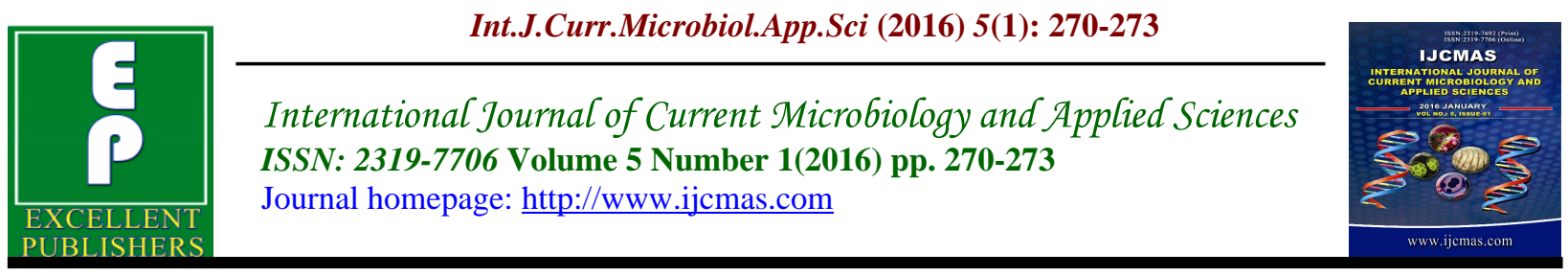

Original Research Article

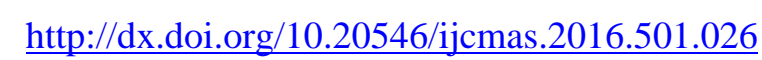

\title{
Preliminary Nutritional Analysis and Phytochemistry of Smilax ovalifolia Leaves
}

\author{
Rajesh Kumar Shah* \\ Department of Zoology, D.H.S.K. College, Dibrugarh, Assam, India \\ *Corresponding author
}

\begin{tabular}{|c|c|}
\hline & B S T R A C T \\
\hline ywords & \multirow{3}{*}{$\begin{array}{l}\text { The present study deals with the evaluation of certain essential nutrients and } \\
\text { phytochemical analysis of the leaves of Smilax ovalifolia. Phytochemical analysis } \\
\text { of the leaf extract showed the presence of various phytochemicals tested for like } \\
\text { carbohydrate, protein, amino acid, saponin, alkaloid, steroid, terpenoid, phenol, } \\
\text { glycoside and flavanoid. The nutritional analysis revealed that the dry leaves } \\
\text { contain high amounts of crude fiber, followed by protein, carbohydrate and } \\
\text { appreciable amounts of lipid and amino acids. Vitamin } \mathrm{C} \text { and vitamin } \mathrm{E} \text { were found } \\
\text { to be } 0.03 \pm 0.008 \mathrm{mg} / \mathrm{g} \text { and } 0.04 \pm 0.023 \mathrm{mg} / \mathrm{g} \text { respectively. Mineral analysis of the } \\
\text { leaves showed the presence of various inorganic minerals like } \mathrm{S}, \mathrm{P}, \mathrm{Mg} \text {, Ca and Fe. } \\
\text { The nutritive value was found to be } 49.93 \mathrm{Kcal} / 100 \mathrm{~g} \text {. The overall data thus } \\
\text { supports the conclusion that this plant represents a useful dietary source and can be } \\
\text { use as an alternative source of vegetable for human consumption. }\end{array}$} \\
\hline & \\
\hline & \\
\hline
\end{tabular}

\section{Introduction}

Medicinal plants play an important role in any community. Several drugs have been successfully prepared from these medicinal plants till date and many are on process. Some of the medicinal plants are also used as vegetable. Smilax ovalifolia belongs to the family Smilacaceae and is widely used by different tribes and medicinal practitioners for treating of various diseases. Tender leaves and fleshy young shoots are also eaten as vegetables in various parts of NE India (Patiri and Borah, 2007; Baruah, et al., 2013 \& Pfoze et al., 2011) and Nepal (Acharya and Acharya, 2010 \& Uprety et al., 2012).
Good nutrition is a big problem in many countries and hence the demand of natural food having high nutritive value is increasing. The study of nutritive value of such plants is therefore very important. The plant selected for study is used as food as well as for treating various diseases in different regions. This is a wild plant, easily available and no systematic study has been carried out so far. So, the present study was undertaken. The main goal of this study was thus to determine the content of certain essential nutrients in the plant sample. 


\section{Materials and Methods}

Fresh leaves were collected, shade dried, grinded to powder and stored in air tight container. Aqueous extract was prepared by hot water extraction method. Organic extracts were prepared by Soxhlet extraction. The extracts obtained were dried and dissolved in DMSO for further use. Qualitative phytochemical analysis was done following standard methods (Sadasivam and Manickam, 1996; Tyler, 1994 \&, Harborne, 1973). Standard methods were also adopted for quantification of various nutrients. Total carbohydrate content was estimated by Anthrone method (Sadasivam and Manickam, 1996). Total protein was estimated by Lowry's method (Lowry et al., 1951).

Quantification of amino acids and crude fiber by the method described by Sadasivam and Manickam (Sadasivam and Manickam, 1996). Estimation of lipids by method of Folch and Unni (Folch et al., 1957 and \& Unni et al 1996). Estimation of Vitamin C was carried out by Folin phenol reagent method (Jagota, and Dani, 1982) and Vitamin E by spectrophotometric method (Prieto et al., 1999). Qualitative estimation of some minerals was carried out by standard methods (Santra et al., 1999). The nutritive value was finally determined by the formula: Nutritive value $=4 \times$ percentage of protein $+9 \times$ percentage of fat $+4 \times$ percentage of carbohydrate (Indrayan et al., 2005).

\section{Results and Discussion}

Phytochemical analysis of the leaf extract showed the presence of various phytochemicals which is summarized in Table I. The medicinal value of any plant lies in these phytochemicals.

These are non-nutritive chemicals that have protective or disease preventive property. The phytochemicals are reported to have therapeutic properties such as insecticidal, antibacterial, antifungal antimalarial, antihelminthic and anticonstipative activities etc.

The main goal of the study was to determine the content of certain essential nutrients in the plant sample which is consumed by certain tribes. The nutritional evaluation is shown in Table II.

Table.1 Qualitative Phytochemical Analysis of the Leave Extracts

\begin{tabular}{|l|l|c|c|c|c|c|}
\hline S1.No. & Phytocompounds & $\begin{array}{l}\text { Aqueous } \\
\text { Extract }\end{array}$ & $\begin{array}{l}\text { Methanolic } \\
\text { Extract }\end{array}$ & $\begin{array}{l}\text { Ethanolic } \\
\text { Extract }\end{array}$ & $\begin{array}{l}\text { Petroleum } \\
\text { Ether Extract }\end{array}$ & $\begin{array}{l}\text { Chloroform } \\
\text { Extract }\end{array}$ \\
\hline 1 & Carbohydrate & + & + & + & - & - \\
\hline 2 & Protein & + & + & + & - & + \\
\hline 3 & Amino acid & + & + & + & - & - \\
\hline 4 & Saponin & + & + & + & - & - \\
\hline 5 & Alkaloid & - & + & + & + & - \\
\hline 6 & Steroid & - & + & + & - & + \\
\hline 7 & Terpenoid & - & + & + & + & + \\
\hline 8 & Phenol & - & + & + & + & - \\
\hline 9 & Glycosides & - & + & - & - & + \\
\hline 10 & Flavonoid & - & - & + & + & - \\
\hline
\end{tabular}


Table.2 Results of Preliminary Nutritional Evaluation

\begin{tabular}{|l|l|l|}
\hline Sl.No. & Constituents & $\begin{array}{l}\text { Amount present } \\
\mathrm{mg} / \mathrm{g} \text { wt } \pm \text { SD }\end{array}$ \\
\hline 1 & Carbohydrate & $31.40 \pm 0.009$ \\
\hline 2 & Protein & $48.23 \pm 0.166$ \\
\hline 3 & Amino acid & $13.12 \pm 0.058$ \\
\hline 4 & Lipid & $20.09 \pm 0.100$ \\
\hline 5 & Ascorbic acid & $0.03 \pm 008$ \\
\hline 6 & Vitamin E & $0.04 \pm 0.023$ \\
\hline 7 & Crude fiber & $256.50 \pm 0.338$ \\
\hline
\end{tabular}

The nutritional analysis revealed that the dry leaves contain high amounts of crude fiber, followed by protein, carbohydrate and appreciable amounts of lipid and amino acids. Vitamin $\mathrm{C}$ and vitamin $\mathrm{E}$ were found to be $0.03 \pm 0.008 \mathrm{mg} / \mathrm{g}$ and $0.04 \pm 0.023$ $\mathrm{mg} / \mathrm{g}$ respectively. The dietary fibers are very important as it decreases the risk of various disorders such as diabetes, cardiovascular diseases, obesity and constipation. Vitamin $\mathrm{C}$ and $\mathrm{E}$ acts as antioxidants and are of profound importance to our body. Mineral analysis of the leaves showed the presence of various inorganic minerals like $\mathrm{S}, \mathrm{P}, \mathrm{Mg}, \mathrm{Ca}$ and $\mathrm{Fe}$. The nutritive value was found to be 49.93 Kcal/100g. The overall data thus supports the conclusion that this plant represents a useful dietary source and can be use as an alternative source of vegetable for human consumption.

\section{Acknowledgement}

The author is thankful to the Assam Science Technology and Environment Council (ASTEC), Dept. of Science and Technology, Govt. of Assam for providing financial support to carry out this research work.

\section{References}

Acharya, K.P., Acharya, R. 2010. Eating From the Wild: Indigenous Knowledge
On Wild Edible Plants In Parroha Vdc Of Rupandehi District, Central Nepal. I.J.S.F., 3(1):28-48.

Baruah, S., Borthakur, S.K., Gogoi, P., et al.2013. Ethnomedicinal Plants Used by Adi-Minyoug tribe of Arunachal Pradesh, East Himalaya. Indian J. Nat. Prod. Resour., 4(3):278-283.

Folch, J., Lees, M., Sloane, S.G.H. 1957. A simple method for the isolation and purification of total lipides from animal tissues. J. Biol. Chem., 226:497-509.

Harborne, J. B. 1973. Phytochemical methods. Chapman and Hall. London.

Indrayan, A.K., Sharma, S., Durgapal, D., et al. 2005. Determination of nutritive value and analysis of mineral elements for some medicinally valued plants from Uttraranchal. Curr. Sci., 89:12525.

Jagota, S.L., Dani, H.M. 1982. A new colorimetric techniques for the estimation of vitamin $\mathrm{C}$ using Folin phenol reagent. Anal. Biochem., 127:178-82.

Lowry, O.H., Rosebrough, N.J., Farr, A.L., et al. 1951Protein measurement with the Folin phenol reagent. J. Biol. Chem., 193:265-75.

Patiri, B., Borah A. 2007. Wild Edible Plants of Assam published by the Director Forest Communication, Forest Department, Assam, Pp 147. 
Pfoze, N.L., Kumar, Y., Myrboh, B. 2011. Survey and assessment of floral diversity on wild edible plants from Senapati district of Manipur, Northeast India. J. Bio. \& Evn. Sci., 1(6):50-62.

Prieto, P., Piveda, M., Aguilar, M. 1999. Spectrophotometric quantitation of antioxidant capacity through the formation of phosphomolybdenum complex specific application to the determination of Vitamin E. Anal. Biochem., 269:337-41.

Sadasivam, S. and Manickam, A. 1996. Biochemical Methods for Agricultural Sciences. New Age International (P) Ltd., New Delhi.

Santra, S.C., Chatterjee, T.P., Das, A.P. 1999. College Botany Practical
(Volume I). New Central Book Agency (P) Ltd.Pp 70-71

Tyler, V. 1994 Phytomedicines in Western Europe: their potential impact on herbal medicine in the United States Herbalgram.30, 24-30.

Unni, B.G., Kakoty, A.C., Khanikor, D., et al. 1996. Lipid and fatty acid composition of muga silkworm, Antheraea assama, host plants in relation to silkworm growth. J. Lipid Mediat. Cell Signal., .13:295-300

Uprety, Y ., Poudel, R.C., Shrestha, K.K., et al. 2012. Diversity of use and local knowledge of wild edible plant resources in Nepal. J. Ethnobiol. Ethnomed., 8:16.

\section{How to cite this article:}

Rajesh Kumar Shah. 2016. Preliminary Nutritional Analysis and Phytochemistry of Smilax ovalifolia Leaves. Int.J.Curr.Microbiol.App.Sci. 5(1): 270-273

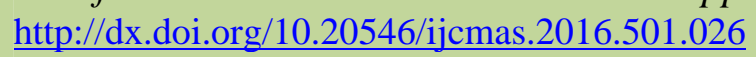

